\title{
International Journal of Case Reports (IJCR)
}

\section{Stammering -Ayurvedic Management with Sookshma Aushadhi Chikitsa -A Case Report}

\author{
Vd.Shivani Sanjeev Gavande. M.D.(Ayu) \\ Associate Professor in Kayachikitsa \\ Dr .J.J .Magdum Ayurved Medical College, Jaysingpur.
}

\begin{abstract}
A patient suffering from stammering since childhood was treated with Tota Vati for six months, got resque from his suffering and now is acting confidently in play. He can speak fluently now. In Ayurved, sookshma aushadhi chikitsa is the most popular system of management where we can get better result with processed microfined particals of the same medicine even at very *Correspondence to Author: low dose .Ayurved says, when the medicine is reprocessed with the decoction of same ingredients repeatedly, we get better efficacy with very small quantity of medicine. Tota vati is such type of processed medicine which was prepared by Vaidya .Narhar Bhole Prabhu.These tablets are much more useful in stammering.

Vd.Shivani Sanjeev Gavande. M.D.(Ayu)

Associate Professor in Kayachikitsa Dr .J.J .Magdum Ayurved Medical College, Jaysingpur.

How to cite this article:

Vd.Shivani Sanjeev Gavande. Stammering -Ayurvedic management with Sookshma aushadhi chikitsa -A case Report . International Journal of Case Reports, 2017 1:1
\end{abstract}

Key words: Stammering, Sookshma Aushadha, Ayurved, Herbal medicine, Tota vati.

\section{eSciencePublisher}

eSciPub LLC, Houston, TX USA. Website: http://escipub.com/ 


\section{Introduction:}

Ayurved has mentioned certain methods of preparations of Herbal drugs. Apart from juice, decoction, powders, tablets, paste of herbal drugs; there are certain methods of sookshmikaran in Bhaishajyakalpana i.e.pharmacognocy of Ayurved. Sookshma means minute like nano particle. When any herbal powder is churned continuously with its decoction, its efficacy increases several times.

Same method of preparation can be very much cost effective when Ayurvedic medicine is prepared along with combination with gold silver etc. Tota Vati is herbal preparation made by the process of sookshmikaran

\section{Materials and Methods:}

Age 17 years.

c/o stammering since childhood

Family history: Brother-Stammerring since childhood

On examination,

No anatomical abnormality found in mouth(No tongue tie.)

Haemodynamically stable.

Patient was given Tota vati 2 BD after food for six weeks

.Before treatment the voice of patient was recorded. The follow up was taken about pronunciation of words.

After six months he showed fluency in speaking.

Methodology:

Main ingredients of Tota vati are as follows,

GUDUCHI

( Tinospora cordifolia )

APAMARGA

( Achyranthus aspera )

VIDANG

(Embelia ribes )

SHANKHPUSHPI

( Convolvulus pluricaulis )

VACHA

( Achorus calamus )
HARITAKI

KUSHTHA

SHATAVARI

KIRATTIKTA

SHUNTHI

( Terminalia chebula )

( Saussurea luppa )

(Asparagus racemosus )

( Swartia chirata )

( Zinziber officianale )

The medicine, Tota vati was prepared by $\mathrm{Vd}$. Narhar Bhole Prabhu. He is having his own pharmacy for preparation of sookshma aushadhi.Tincture was made with above medicines and was mixed with sugar balls to administer in patient for six months.

\section{Discussion:}

The disease Minmin is quoted in vaat vyadhi in Ayurved. Though tongue is the organ for speaking ,Ayurved does not include this disease in Mukharog ,instead it is included in vaat vyadhi .According to Samprapti(etiopathology) of Mimin, Vitiated vaat dosha due to Kapha dushti,obstructs shabdvahi dhamanya. So patient is unable to utter the consonants properly . He hesitates to utter first word and even can't speak fluently.

Modern system of medicine includes stammering in nervous disorder as Aphasia .Motor and sensory nerves related to speech centre in hypothalamus. Verbal aphasia is pure motor aphasia. . Inability to speak articulately is seen in Minmin. Motor mechanism is intact. There is no intellectual defect .Lesions lies at the anterior to lateral end of precentral gyrus ( Broca's area )

Ayurvedic drugs used in this formula mainly works on Medha and also on Kanth. For utterance of word,proper coordination of brain (nervous systeme)as well as larynx is required.The nano particals of herbal drugs act on these systems in effective way with a very low dose

The Karmukata of drugs are as follows (Table 1):

\section{Conclusion:}

Patient got complete relief now and he is able to speak fluently.

Sookshma aushadhi chikitsa is cost effective and fast acting Ayurvedic treatment .Tota vati in stammering patient worked effectively.. 
With this procedure of Sookshma chikitsa many Ayurvedic medicines can be made available in more quantity along with lesser cost.

\section{Reference:}

[1] Charak Samhita. Chakrapaani commentary.

[2] Sooksma Chikitsa -Vaidya Narhar Bhole Prabhu.

[3] Bhaishajya kalpana Vidnyaan.

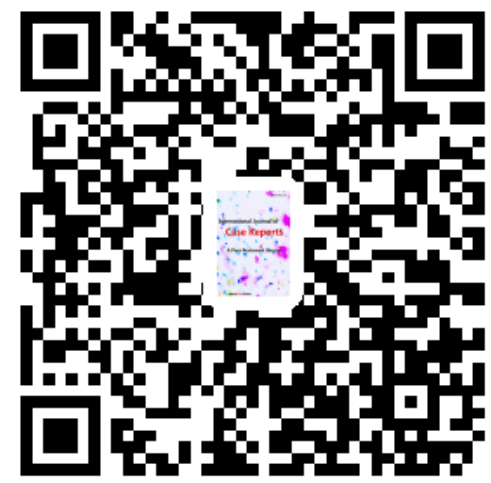

\begin{tabular}{|c|c|c|c|c|c|}
\hline DRUG & RASA & GUNA & VEERYA & VIPAAK & DOSHA-KARMA \\
\hline GUDUCHI & $\begin{array}{l}\text { Tikt Ka- } \\
\text { shay }\end{array}$ & Snigdh & Ushn & Madhur & Kafaghna Rasayan \\
\hline APAMARGA & Tikt Katu & $\begin{array}{l}\text { Laghu } \\
\text { Ruksh }\end{array}$ & Usna & Katu & $\begin{array}{c}\text { Kafaghna Shirovirechananam } \\
\text { Shrashthah }\end{array}$ \\
\hline VIDANG & Katu & $\begin{array}{l}\text { Laghu } \\
\text { Ruksha }\end{array}$ & Ushna & Katu & $\begin{array}{c}\text { Kafaghna Shirovirechan Ras- } \\
\text { ayan }\end{array}$ \\
\hline $\begin{array}{l}\text { SHANKHPUSH- } \\
P I\end{array}$ & $\begin{array}{c}\text { Kashay } \\
\text { Katu Tikt }\end{array}$ & $\begin{array}{l}\text { Snigdh } \\
\text { Guru Sar }\end{array}$ & Sheet & Madhur & Medhakrut \\
\hline VACHA & Tikt Katu & $\begin{array}{l}\text { Laghu } \\
\text { Teekshna }\end{array}$ & Ushna & Katu & Kanthya Medhya \\
\hline HARITAKI & $\begin{array}{c}\text { Panch } \\
\text { Ras }\end{array}$ & $\begin{array}{l}\text { Laghu } \\
\text { Ruksha }\end{array}$ & Ushna & Madhur & $\begin{array}{c}\text { Medhya } \\
\text { Rasayani } \\
\text { Unmilani Buddhibalendriyaa- } \\
\text { naam } \\
\end{array}$ \\
\hline KUSHTHA & Tikt Katu & $\begin{array}{l}\text { Laghu } \\
\text { Rukash } \\
\text { Teekshna }\end{array}$ & Ushna & Katu & Kafaghna Aakshephar \\
\hline SHATAVARI & $\begin{array}{c}\text { Tikt } \\
\text { Madhur }\end{array}$ & $\begin{array}{c}\text { Guru } \\
\text { Snigdha }\end{array}$ & Sheet & Madhur & Medhyaa \\
\hline KIRATTIKTA & Tikt & $\begin{array}{l}\text { Laghu } \\
\text { Ruksh }\end{array}$ & Sheet & Katu & Kafaghna \\
\hline SHUNTHI & Katu & $\begin{array}{l}\text { Laghu } \\
\text { Snigdh }\end{array}$ & $\begin{array}{l}\text { Ushnavee- } \\
\text { rya }\end{array}$ & Madhur & $\begin{array}{c}\text { Kafaghna Swarya } \\
\text { Jivha Kanth Vishodhana }\end{array}$ \\
\hline
\end{tabular}

